\title{
SUCCESS FACTORS FOR TAIWANESE CONTRACTORS COLLABORATING WITH LOCAL CHINESE CONTRACTORS IN CONSTRUCTION PROJECTS
}

\section{Chih-Han KAO ${ }^{1}$, Cheng-Han HUANG ${ }^{2}$, Mark Shu-Chien HSU ${ }^{3}$, I-Hung TSAI ${ }^{4}$}

${ }^{1}$ Civil and Engineering Management, National Quemoy Univesity, No. 1, University Rd., Jinning Township, Kinmen County 892, Taiwan R.O.C

${ }^{2}$ Taiwan Construction Research Institute, $11 F$, No9, Sec2, Chung-Hsing Rd., Hsintien, Taipei, Taiwan

${ }^{3}$ Department of Civil and Environmental Engineering, Hong Kong Polytechnic University, ZS944, 9/F, Block Z, Hong Kong Polytechnic University, Hung Hom, Hong Kong

${ }^{4}$ Cathay Real Estate Development Co., Kaoshung, Taiwan

E-mails: ${ }^{1}$ siokao1020@yahoo.com.tw (corresponding author); ${ }^{2}$ jasper@tcri.org.tw;

3mark.hsu@polyu.edu.hk; ${ }^{4}$ kobehouse2003@yahoo.com.tw

Received 14 July 2015; accepted 29 December 2015

\begin{abstract}
Regional trade cooperation has become an important component of construction industry due to the Free Trade Agreement. This segment of the market presents many challenges for construction firms. Establishing suitable international partnering relations is an effective strategy for adapting to the additional unpredictability of international markets. This research integrates the Balanced Scorecard system with Fuzzy Analytic Hierarchy Process for comprehensive and quantitative evaluation of the relevant bilateral cooperation. Commercial cooperation across the Taiwan Strait is selected as a case study for determining the evaluating methodology. After examining data from Chinese firms, 12 factors for partner selection are identified. The factors are compared with practical conditions of worldwide and local markets to establish their viability. The methodology provides a framework for evaluating potential partners when attempting to enter foreign markets. Additionally, it identifies critical factors for developing optimal market entrance strategies, contracts, and risk management; results can also be golcally (globally and locally) tailored to promote the efficiency of international cooperation.
\end{abstract}

Keywords: partnering relationship, Balanced Scorecard, Fuzzy Analytic Hierarchy Process, Chinese construction market, Taiwan, contractor, regional economic.

JEL Classification: F23.

\section{Introduction}

In 2010, through quick and massive economic development China became the largest construction market (Betts et al. 2011; Chao 2011). However, many international construction companies wanting to enter China's construction market face strict policies protecting domestic companies. For example, some foreign firms overcame the difficult 
requirements for setting up construction or design operations and compete directly with Chinese construction companies by forming project management consultancy firms that did not need a qualification from the MOC (Ministry of Construction) (Wallack 2005). Therefore there are a few mega-projects opening for international investment through Build-Operate-Transfer (BOT) contracts or projects with special technical requirements, such as power plants, sewage treatment plants, and high-tech factories (Chao 2011). Moreover, there also are experience, personnel, limits to scope of work and capitalisation requirements to be met by the FIE (Foreign-Invested Enterprises) (Wallack 2005), all of which has limited the percentage of FIE contractors in China to $0.84 \%$ (NBSC 2014).

P.R.C. (People's Republic of China) and Taiwan signed the ECFA (Economic Cooperation Framework Agreement) in 2010. Moreover, P.R.C. had claimed the regional cooperating policy of "Silk Road Economic Belt" and the "21st Century Maritime Silk Road" in 2014. Thus there is a greater possibility of opening their construction markets to each other. The Chinese government indicated that as of 2009 the West Straits Special Economic Zone had a more flexible policy for commercial affairs with Taiwan. Although Taiwan's construction companies have some advantages, such as a similar language and cultural background, and are located in the same economic region, they still lack the necessary investment information. In order to reduce the difficulty of entering China's market, this study first reviews the literature related to the investment environment of China (Gunhan, Arditi 2005; Ling et al. 2006; Lu et al. 2008; Xu et al. 2005), and then concludes that the use of the Strategic Alliance to cooperate with local construction companies is a feasible method to start a business in China. Due to the strict policies protecting domestic companies, the key to entering China's construction market is to cooperate with local companies. A previous study proposed the incentive of strategic partnering in China from a construction companies' point of view ( $\mathrm{Lu}$, Yan 2007). It proved that the willingness of host national companies was an important factor for successful partnering. The study also pointed out that profit is the most important factor influencing the willingness of partnering from the part of the respondents. However, there is still a lack of knowledge concerning the key factors in successful partnering during the pairing phase. Such knowledge will be beneficial if such a study can provide information on the demand on cooperation on the host country's companies.

This study utilises the Balanced Scorecard (BSC) as a framework to build the cooperative structure for organisations to improve their competitive ability, then it uses a questionnaire survey to determine the initial impact factors involving a partnering relationship (PR) between Taiwan's construction companies and China's local companies. Although the BSC is a useful tool for analysing and summarise the list of metrics, it lacks the quantifying ability to prioritise these factors. Therefore, the second step of this study is to quantify the factors through another questionnaire survey involving the companies of the host country, and then to identify the key factors by the Fuzzy Analytic Hierarchy Process (FAHP). These factors can be a reference for companies of the host country selecting cooperative partners when entering the construction market in China. A comparison between the results and the practical situation is also discussed. 


\section{Partnering relationship in construction}

The PR is based upon trust, dedication to common goals, and having an understanding of each other's individual expectations and values. Expected benefits include improved efficiency and cost-effectiveness, increased opportunity for innovation, and the continuous improvement of quality products and services.

Some studies have discussed the successful factors and characteristics of construction partnering (Cheng et al. 2000; Cheng, Li 2002; Mohr, Spekman 1994). Cheng et al. (2014) proved that PR development has a positive influence on construction project performance.

Li et al. (2001) cited that successful PR is based on a complementary resources perspective. This can enhance the competitive ability of a collaborating organisation. Other research studies focus on building alliances and collaborations to penetrate international markets, such as in China (Xu et al. 2005). Cheng and Li (2002) investigated the relationship between success factors and the construction partnering process. Ozorhon et al. (2011) proposed a multidimensional model for measuring international joint venture performance. These studies show how important the PR is in the construction industry. While much knowledge has been collected on the adoption and evaluation of the PR in the construction industry, little is known about the appropriate partner selection resulting from the complementary resources perspective.

In the initial stage of a cooperative project, it is difficult to evaluate which partner has a higher degree of fitness. The degree to which a partner fits into two main manifestations depends on the strategic and operational fit for capturing the common concepts and concern with the similarity between partners. Lewis (1990) provided an evaluation standard that includes three major categories for the selecting partner: combined strength, compatibility, and commitment. This study was based on the assumption that the Chinese local partner evaluates the potential partner without issues of commitment in the pairing phase. It utilized the category concept from Lewis' (1990) and Morris and Cadogan's (2001) studies to develop the success partnering factors for selecting Chinese local partners.

\section{Balanced scorecard and the first survey}

$\mathrm{BSC}$ is a strategic performance management tool. The original thinking behind BSC was for it to focus on information related to the implementation of a strategy. BSC was utilised to transfer strategy and targets into a standard for an organisation's performance. Actually executing those strategies may ensure that the organisation will achieve excellent performance (Kaplan, Norton 1996; Abdullah et al. 2013). Not surprisingly, over time there has been a blurring of the boundaries between conventional strategic planning and control activities and those required to design a BSC. It is proposed that companies have to involve both sides of the operating management from internal and external environments.

There are few related researches of BSC in construction. For example, Kagioglou et al. (2001) had developed a conceptual framework for evaluating contractors' project per- 
formance by BSC approach. A partnering organization can be treated as a company. Therefore, Lo et al. (2006) has proposed that utilized BSC to measure performance of partnering projects.

To achieve excellent performance of construction project, the future partnering organisation must have the terms which develop from BSC approach. Therefore, the terms are an important evaluating reference for the partner selection of contractor. According to this rule of BSC and from the point of view of an organisation's competition strategy, this study summarised 22 factors from previous studies which were related to a successful cooperative strategy in the of construction market in China (Ling et al. 2006; $\mathrm{Lu}$ et al. 2008). This research categorised those factors into four perspectives of BCS as our initial evaluation measures for the first survey. The objective of the survey is to identify which factors are important for partnering in the construction industry between Taiwan and China in regional economic communities. This study utilised the wellknown five-level Likert scale to design the questionnaire. The questionnaire defined that "highly important" gets a score of 5, "important" 4, "normal" 3, "less important" 2, and "unimportant" 1. The questionnaire developed was used to interview 129 companies, which included 85 contractors and 44 consulting firms in the Taiwan Straits West Coast

Table 1. Statistical results of the preliminary questionnaire survey

\begin{tabular}{|c|c|c|}
\hline Perspective & Factors & Mean \\
\hline \multirow{5}{*}{ Financial } & Investment ability & $* 2.54$ \\
\hline & Price fluctuation resistibility & $* 2.04$ \\
\hline & Financing ability & $* 1.87$ \\
\hline & Stable cash flow & 1.56 \\
\hline & Cost management & 1.32 \\
\hline \multirow{5}{*}{ Customer } & Flexibility of change order & $* 1.81$ \\
\hline & Enterprise image and culture & 1.64 \\
\hline & Relationship with government departments & 1.44 \\
\hline & Relationship with owners & 1.34 \\
\hline & Contract management & 1.30 \\
\hline \multirow{8}{*}{$\begin{array}{l}\text { Internal } \\
\text { Business } \\
\text { Processes }\end{array}$} & Cultural difference with potential partners & $* 2.24$ \\
\hline & Similar strategy to potential partners & $* 1.98$ \\
\hline & Availability of materials and equipment & $* 1.87$ \\
\hline & Relationship with subcontractors & $* 1.73$ \\
\hline & Information management & $* 1.72$ \\
\hline & Communication and coordination between functional departments & 1.65 \\
\hline & Project schedule and time management & 1.53 \\
\hline & Interaction between management and general staffs & 1.51 \\
\hline \multirow{4}{*}{$\begin{array}{l}\text { Learning } \\
\text { and Growth }\end{array}$} & Technology innovation ability & $* 1.82$ \\
\hline & Complementary technology & $* 1.77$ \\
\hline & Sustainable development of technology & $* 1.73$ \\
\hline & Capacity of human resource & 1.42 \\
\hline
\end{tabular}

Note: *denotes a key factor. 
Economic Zone in China. The turnover of the interviewed companies ranged from 100 million United States Dollars (USD) to 200 million USD. The statistical results of the survey are shown in Table1. The average mean of the factors is 1.72 , and the standard deviation of the interval is 0.04 . According to Table 1 , the mean value of the "Communication and coordination among functional departments" factor is 0.07 , lower than the "Information management" factor, which means it is outside the standard deviation of the survey. Therefore, the 12 factors with mean values higher than 1.72 were identified as important factors in the preliminary survey.

\section{Fuzzy Analysis Hierarchy Process (FAHP) survey}

The next step was to develop another questionnaire based on FAHP for the second stage survey. Analytic Hierarchy Process (AHP) is an extensively-used multi-criteria decision-making method (Saaty 1978). The main advantage of AHP is the relative ease with which it handles multiple criteria. The methodology of AHP is easy to understand and it can effectively handle both qualitative and quantitative data. Although the purpose of AHP is to capture expert's knowledge, conventional AHPs cannot reflect the human reasoning process. The fuzzy extension of AHP was developed to solve hierarchical problems (Saaty 1978; Samvedi et al. 2013). FAHP has the following superior functions: it can solve problems that are difficult to describe using traditional quantitative methods; it can clarify the fuzzy recognition of factors evaluation from those experts who has filled the questionnaire and will not reject any of the respondents' special concepts; and it can also provide a flexible reference for a decision by a group of experts (Banai-Kashani 1990).

The FAHP survey in this study targeted the same 129 companies as the BSC survey, and 129 questionnaires were distributed to their headquarters. Within a month, 94 valid responses (there were 71 contractors and 23 consulting in the host country) were returned, which constituted a response rate of $73 \%$. We then utilised the FAHP to analyse those responses. The first step outlines the extent of the analysis using FAHP, and then this method is applied to the factor selection problem (Mahmoodzadeh et al. 2007).

As mentioned previously, the FAHP of this study is focused on the integration of the knowledge of experts. The study utilised the fuzzy sets in the computing process of the AHP, which replaced the crisp values of the comparison matrix. The computing processes can be described as follows:

Step1: Defining the fuzzy sets of the importance score of goal key factors.

This study utilised a questionnaire to obtain the importance score for the key factors of successful partnering from a pair-wise comparison by experts:

$$
\text { Let } \tilde{A}_{i}^{j}=\left(l_{i}^{j}, m_{i}^{j}, u_{i}^{j}\right) \text {, }
$$

where: $\tilde{A}_{i}^{j}$ - the fuzzy sets of the importance score; $n$ - the number of key factors; $i-$ the $i$ th goal of the key factors of successful partnering $i=1$ to $n ; j-$ the $j$ th comparison of key factors of successful partnering $i=1$ to $n$; $l_{i}^{j}$ - the value of lower boundary of the importance score; $m_{i}^{j}$ - the value of the middle boundary of the importance score; $u_{i}^{j}-$ the value of the upper boundary of the importance score. 
The study defined the importance score of the lowest boundary of the fuzzy set using the lowest value that the $i$ th goal of the key factors of successful partnering as evaluated by a questionnaire to the experts. The equation for the lowest boundary is:

$$
l_{i}^{j}=\min _{j=1 \text { to } n} s_{i}^{j} \text {. }
$$

The study defined the importance score of the mid value of the fuzzy set using the hyper average value that the $i$ th goal of the key factors of successful partnering which was evaluated from expert feedback. The equation for the mid value is:

$$
m_{i}^{j}=\left(\prod_{j=1}^{n} s_{i}^{j}\right)^{\frac{1}{n}} \text {. }
$$

The study defined the importance score of the fuzzy set highest boundary using the lowest value that the $i$ th goal of key factors of successful partnering which was evaluated from expert feedback. The equation for the highest boundary is:

$$
u_{i}^{j}=\max _{j=1 \text { to } n} s_{i}^{j} \text {. }
$$

Step 2: Normalise the boundary value of fuzzy sets of importance score.

The study utilised the following equations before the next step to defuzzify the fuzzy sets of the importance score. The equations to normalise the boundary value are:

$$
\begin{gathered}
l_{i}^{\prime j}=\frac{\left[\left(\sum_{i=1}^{n} u_{i}^{j}\right) \times\left(\sum_{i=1}^{n} l_{i}^{j}\right)\right]^{\frac{1}{2}}}{m_{i}^{j}=\frac{m_{i}^{j}}{\sum_{i=1}^{n} m_{i}^{j}} ;} \\
u_{i}^{\prime j}=\frac{u_{i}^{\prime}}{\left[\left(\sum_{i=1}^{n} u_{i}^{j}\right) \times\left(\sum_{i=1}^{n} l_{i}^{j}\right)\right]^{\frac{1}{2}}} .
\end{gathered}
$$

Step 3: Defuzzifying the fuzzy set of the importance score.

The study utilised the centre of gravity defuzzification method to defuzzify the equation and compute the fuzzy number of the importance score. The defuzzifying number is calculated as:

$$
D F_{i}^{j}=\frac{\left[\left(u_{i}^{\prime j}-l_{i}^{\prime}\right)+\left(m_{i}^{\prime j}-l_{i}^{\prime i}\right)\right]}{3}+l_{i}^{\prime j},
$$

where: $D F_{i}^{j}$ - the fuzzy number of the importance score.

Moreover, $D F_{i}^{j}$ needs to be normalised before the subsequent computing process of the original AHP. The equation is as follows: 


$$
D F_{i}^{\prime j}=\frac{D F_{i}^{j}}{\sum_{i=1}^{n} D F_{i}^{j}} .
$$

Step 4: Weight computation process by the original AHP.

The above-mentioned result of $D F_{i}^{j}$ was utilised to replace the crisp value for the computation of the original AHP. In this step, this study computed the importance weight through the process as follows: build a matrix of eigenvectors, compute the corresponding weight matrix, and compute the total weight matrix. Via the unity weight matrix, the importance weights of the 12 key factors of successful partnering were obtained in this study. Those equations are as follows:

for $k=1,2, \ldots, n ; k \neq i$, then the weight vector is given by:

$$
W^{\prime}=\left\{D F_{1}^{\prime}, D F_{2}^{\prime}, \ldots, D F_{n}^{\prime}\right\}^{T},
$$

where: $W^{\prime}$ - the corresponding weight matrix of the key factors.

Moreover, this study confirmed the improvement of the FAHP over AHP by the consistency ratio (C.R.) (Saaty 1978). This proves the effect of knowledge integration of the FAHP is more effective than that of the AHP's.

Figure 1 gives the basic results from the use of FAHP in this study. The consistence degree is 0.04 and the CR is 0.03 . Both numbers are qualified for the standards of Saaty's

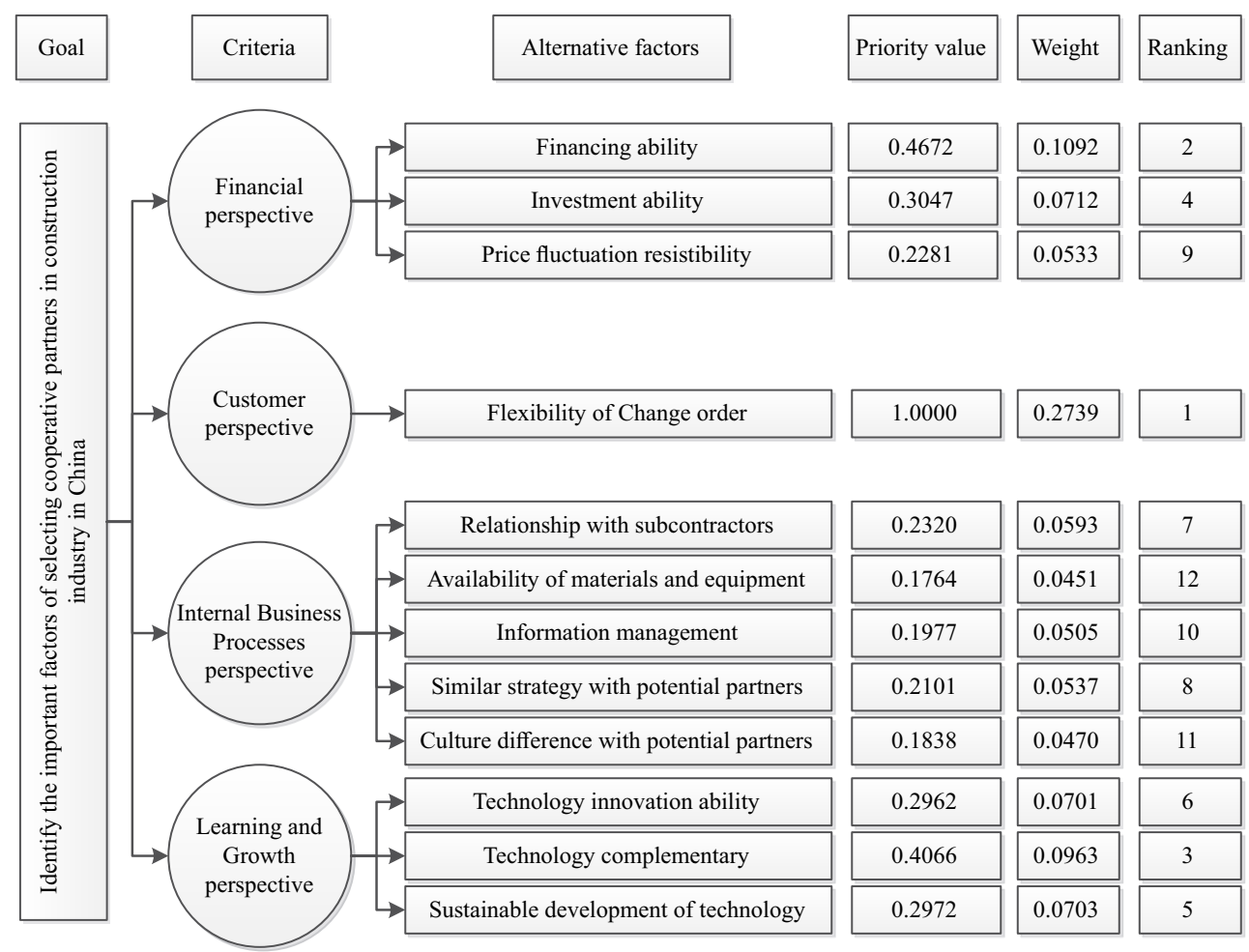

Fig. 1. FAHP analysed results 
consistency test (Saaty 1978), and show that the result has a high consistency. According to Figure 1, we can determine that the top three factors the interviewees care about are: flexibility of change order, financing ability, and complementary technology. The result gives us 12 significant factors that can be classified into four perspectives.

\section{Factor comparison with practical conditions}

In order to prove the feasibility of the factors that we provided, this chapter considers a comparison of these factors with practical conditions. The comparison is divided into two major perspectives: market-based and policy-based. We selected the top six factors; these cover over $70 \%$ of the weight factors under consideration.

\subsection{Market-based perspective comparison}

Due to a lack of official statistical information on China's construction industry, comparable information concerning China's current construction market was gathered from news reports, industry reports and Chinese government reports. A detailed comparison of the factors and current market conditions in China and worldwide are as follows.

\subsubsection{Flexibility of changes to orders}

Flexibility in the face of changes to orders is the most important factor, which has the highest weight (0.2739) among those factors. Changes often need to be made during a construction project, and it is necessary for the owner to optimise benefits. However, changing orders sometimes causes severe challenges for construction companies. Moselhi's et al. (2005) study had proved that the major impact on labor productivity was caused by the changing orders. Most contractors took responsibility for the costs related to change orders. It is one of the major risks in construction projects in China (Ke et al. 2010). For example, the China Railway Construction Corporation (CRCC) faced a loss of around $\$ 640$ million USD on the Mecca Light Rail Project in Saudi Arabia because of significant changes to orders in 2010 (Construction Week 2011). The reasons for the change orders in this case were: insufficient design drawing in the bidding phase, broken commitment of support from the owner, and too many directions by the owner, among others. These reasons are similar to those for order changes in the majority of cases in China (Zou et al. 2007). Moreover, because technology is evolving so rapidly, many designs become outdated during the actual construction process. The contractor therefore has to take greater responsibility for design throughout the project (Armstrong 2013).

Therefore, it would be beneficial for local companies in China if the cooperative partner could either prevent change of orders from happening, or have greater flexibility in the face of changes to orders. A company that has more flexibility with regard to changing orders should be able to make clear plans and specifications as well as perform a comprehensive pre-bid site inspection. Another key ability to help companies prevent losses from order changes includes a full understanding of contracts and billing. 


\subsubsection{Financing ability}

Financing is the second priority of the factors under consideration. Difficulty in obtaining bank loans is a major constraint for small contractors around the world (Keasey, Watson 1994). A lack of understanding by financial institutions decreases the probability of gaining loan approvals for corporations of any size. The major implications are that securing profitable projects in a competitive market is difficult, and inevitably a decreased access to bank financing influences the construction industry. Nonetheless, $66.28 \%$ of the total capital used for construction projects is supplied by financial institutions (Price, Shawa 1997). The total debt to equity ratio is $48.8 \%$ (NBSC 2013). Moreover, the total debt of Chinese contractors reached over 752.2 billion USD in 2012 (NBSC 2013). The major cause of this debt is the owners of the projects (Fan 2015; Armstrong 2013). Both critical financial situations cause problems for construction companies. Consequently, a cooperative partner that is better able to provide financing and financial management can help improve the performance of China's local companies.

\subsubsection{Complementary technology}

The complementary technology factor is also important for cooperative partners (Chang et al. 2012). Additionally, Lu and Yan (2007) cited that Chinese contractors are more likely to access technology through strategic partnering. Moreover, China has sufficient human and material resources for complex construction projects, however it still lacks the advanced technology and management skills for maintaining the consistent quality

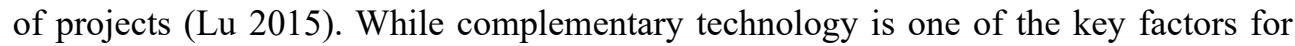
improving the quality of construction projects, we need to know more about transferring technology from other partners. The factors of success for transferring technology include the degree of a firm connectedness to value-creating partner (Liao, Phan 2015).

\subsubsection{Investment ability}

The average wage of a Chinese contractor was $21223 \mathrm{RMB} / \mathrm{year}$ in 2008, and the average wage is almost double in 2013 (NBSC 2014). Labour costs have risen in recent years. For example, the labour cost per square metre was around 33 USD before 2010, and rose to about 135USD per square metre in 2013. This has quadrupled the cost compared with 2005 (BWCHINESE 2011; NBSC 2014). It means that the construction industry in China cannot depend on a traditional, large labour force and low-cost methods to operate their construction projects. Companies should utilise exit strategies to expand and operate their businesses in other fields.

Moreover, Chinese local contractors tended to involve the supply chain of development industries because they provided higher profits than that of other industries (Fan 2015). Therefore, investment ability is quite important to China's local companies when selecting cooperative partners.

\subsubsection{Sustainable development of technology}

According to the new material industry investment analysis and prediction report from 2015 to 2019 from China Investment Consulting (CIC), the new material and technology development market has continued to grow, and will exceed 20 billion USD (CIC 
2009). Not only does the market trend show the potential of the new material and technology industries, but also the Chinese government supports these industries. This information proves that the factor of sustainable development of technology ability is important when selecting cooperative partners.

\subsubsection{Technology innovation ability}

Although in China construction companies have begun to utilise advanced technologies, there is still a lack of management skills, such as professional inspection from owners to improve the quality of projects (Fan 2015). Most small-to-medium sized construction contractors in China are run by family members, who usually lack the concept of strategy management, operational management, and client management. Moreover, the low educational level of construction workers and managers in China limits technology innovation. Additionally, Jiang and Li (2009) had proved that knowledge sharing, knowledge creation and their interaction significantly contribute to partner firms' innovative performance. It is essential for China's construction companies to adopt new technologies and management skills from cooperative partners.

\subsection{Policy-based perspective comparison}

It is significant that China's economic policy now focuses on the industry perspective (Lu 2015). The market economy and policy economy are accommodating. Additionally, each regional economic area has different policies for encouraging investment from the private sector and expanding investment. There are two major policies for encouraging investment from the private sector. The first is to expand financing methods, such as diversifying financing warranties, supporting multiple financing, expanding the scope of investment, and adjusting the capital and debt ratio for projects (Xiamen Municipal Government 2009). The second is that of preferential tax to encourage private sector investment. According to chapter four of China's tax legislation, the scope of preferential tax investment includes carbon emission reduction projects, environmental protection related projects, energy and water saving projects, technology innovation, and financing from private sectors (China Tax Laws 2007). These economic policies will encourage local companies in China to improve their financing ability and adopt advanced technology and materials through cooperative partners.

Finally, to identify possible wider implications of the research results, the authors note that the key factors of the flexibility of changing orders, financing ability, and investment ability are consistent with the results of a worldwide practical survey in the construction industry (Armstrong 2013). The comparable findings indicate that the results of non-technology operating strategy by the BSC-based algorithm are applicable to a wider pool of firms, and not restricted to the specific region studied.

\section{Conclusions}

In a rapidly-developing international construction market, a fruitful research for appropriate cooperative partners is an essential component of success.

However, there is a need for guidelines to guide companies that desire to select suitable partners from among cross-border firms. This research provides a quantitative frame- 
work for evaluating and selecting prospective cooperative partners through double questionnaire surveys with both the BSC and FAHP methods. Moreover, the research utilizes regional commercial cooperation across the Taiwanese strait as a case study for the individual evaluating methodology. The resulting calculations give us 12 significant factors, and the significant findings are taken from the top 6 critical factors.

We also conducted a comparison of the factors, which we summarised with reference to practical conditions of worldwide and local markets to demonstrate the feasibility of the study. The authors find that there are two sources of critical factors: the operating core needs of common construction firms, and the individual environmental needs (policy and finance etc.) of the local market. The results of the case study indicated that host contractors' needs are consistent with the core abilities of worldwide contractors and the unfavorable conditions of host construction industry.

Through previously mentioned results and discussion, the authors found the following associated theoretical implications:

1. Balancing weights between all perspectives of the research, the BSC has been verified as a proper evaluating framework for the operating requirements of ordinary construction firms.

2. This study confirmed the superiority of the FAHP over AHP by the C.R. This proves the consistency of data involving fuzzy sets is more effective than that involving crisp numbers. When the experts' options are hard to clearly describe for the evaluation of BSC, the FAHP is a proper tool for the BSC.

3. The construction industry always hinges on the issue of technology. This study demonstrated that contractors need more than just technology; they also need also important complementary and immediate abilities to adapt to new market conditions.

4. Responsiveness and flexibility in the face of changes to orders is the most important factor for construction organizations; that means the ability to react rapidly to changing specifications of mega project is the vital core competency of construction firms.

5. Through the "financing ability" factor, the authors find that the host contractor cannot always secure sufficient funding through loans, and therefore needs foreign partners who can secure additional loans to expand the scale of international contracting of engineering.

Additionally, there are some related issues about the limitations of the research, as follows:

1. All factors need to be identified whenever evaluating a potential partner's ranking on these scales. The scales can provide a full and quantifiable analysis model that can provide a more precise calculation of results.

2. The mega project and turn-key project are the targeted projects for the partnering organization in the region studied.

3. When other construction firms wish to enter the Chinese market after adapting this research's findings, the factor of cultural differences needs to be taken into account; consequently, the strategy needs to be modified accordingly. 
The construction market in East Asia is opening significantly through regional trade cooperation. Thus, there are some possible practical implications for regional trade cooperation in the worldwide construct industry. The practical implications are as follows:

1. The entering firm faces the barrier of insufficient information regarding entering an unfamiliar market. Importantly, however, firms can refer to the factors of this study when developing or adjusting operational strategies that take into account inherent barriers of the host contractor market. The adjusted operating strategy will create additional value in the international PR.

2. The critical factors listed can also serve as input variables within a partnering selection model. Such a model can expand research into partner selection by incorporating statistical, neural-network, fuzzy, and other prediction-related methodologies. By following the framework of the partner selection model and historical data of the international PR, both sides of the potential international PR can rationally select a suitable foreign partner.

3. The terms of the contract for cooperation can be calibrated by critical factors of this study to clearly define important obligations of each international partner. On a case-by-case basis, the partnering contract will eliminate poor communication stemming from cultural differences.

4. The host contractors' expectations for the potential partner are shaped by their operating risk. Therefore, the entering firm can utilize the critical factors to sharpen its focus on the main risks of foreign market. The process of risk identification can efficiently promote the competition of partnering organization, and reduce the market entry barriers.

In sum, the entering firm can refer to the details of the BSC-based algorithm to investigate the operating requirements of the desired target market. The findings retrieved from this research can be useful reference for developing optimal market entry strategies, stipulating comprehensive contracts, and handling efficient risk management to promote the success of international cooperation.

The regional trade cooperation is a popular trend of world trading and construction industry. The trade mode develops many opportunities, challenges and risk for the construction firms which plan to enter foreign markets. Through the foregoing description, the authors indicate that the construction industry can utilize the BSC-based evaluating algorithm to comprehensively examine and adjust the operating strategic for challengeable and changeable requirement of foreign market. According suitable PR, a ccompetitive construction firm can rapidly emphasize performance of the custom service and the operation by effective responding ability, stable financial management and technology complement. It makes the cooperation more profitable and risk reduction. Furthermore, BSC has been verified as a proper evaluating framework for the operating requirements of ordinary construction firms. However, the modified localize strategic will create value of the entering firm for host construction industry that result of the research is refereed for development of glocalize strategic. 


\section{References}

Abdullah, I.; Umair, T.; Rashid, Y.; Naeem, B. 2013. Developments on balanced scorecard: a historical review, World Applied Sciences Journal 21(1): 134-141.

http://dx.doi.org/10.5829/idosi.wasj.2013.21.1.2314

Armstrong, G. 2013. Global construction survey 2013: ready for the next big wave? 8th ed. Netherlands: KPMG International.

Banai-Kashani, A. R. 1990. Dealing with uncertainty and fuzziness in development planning: a simulation of high-technology industrial location decision making by the analytic hierarchy process, Environment and Planning 22(1): 1183-1203. http://dx.doi.org/10.1068/a221183

Betts, M.; Robinson, G.; Blake, N.; Burton, C.; Godden, D. 2011. Global construction 2020. London, United Kingdom: Global Construction Perspectives and Oxford Economics.

BWCHINESE. 2011. Why the salaries of construction workers are so good in China? [online], [cited 6 October 2014]. Available from Internet: http://www.bwchinese.com/article/1020837.html (in Chinese).

Chang, C. W.; Chang, D. M.; Paic, F. Y. 2012. Cooperative strategy in supply chain networks, Industrial Marketing Management 41(7): 1114-1124.

http://dx.doi.org/10.1016/j.indmarman.2012.04.011

Chao, D. W. 2011. China's construction industry: strategic options for foreign players [online], [cited 21 October 2014]. Available from Internet: http://www.thebeijingaxis.com/tca/editions/thechina-analyst-mar-2011/2.

Cheng, E. W. L.; Li, H. 2002. Construction partnering process and associated critical success factors: quantitative investigation, Journal of Management in Engineering 18(4): 194-202.

http://dx.doi.org/10.1061/(ASCE)0742-597X(2002)18:4(194)

Cheng, E. W. L.; Li, H.; Love, P. E. D. 2000. Establishment of critical success factors for construction partnering, Journal of Management in Engineering 16(2): 84-92.

http://dx.doi.org/10.1061/(ASCE)0742-597X(2000)16:2(84)

Cheng, L. Y.; Wen, D. C.; Jiang, H. C. 2014. The performance excellence model in construction enterprises: an application study with modeling and analysis, Construction Management and Economics 32(11): 1078- 1092. http://dx.doi.org/10.1080/01446193.2014.956131

China Tax Laws. 2007. China tax policies [online], [cited 10 August 2014]. Available from Internet: http://www.gov.cn/flfg/2007-03/19/content_554243.htm (in Chinese).

CIC. 2009. New material industry investment analysis and prediction report from 2010 to 2015 [online], [cited 10 June 2015]. China Investment Consulting. Available from Internet: http://big5. ocn.com.cn/reports/20091013xincailiao.shtml (in Chinese).

Construction Week. 2011. CRCC facing \$640m loss on Mecca Light Rail Project [online], [cited 5 October 2011]. Available from Internet: http://www.constructionweekonline.com/article9921-crcc-facing-640m-loss-on-mecca-light-rail-project

Fan, B. H. 2015. The practical survey for the construction industry in China: Report commissioned by research action. Fuzhou University, Fuzhou, China.

Gunhan, S.; Arditi, D. 2005. Factors affecting international construction, Journal of Construction Engineering and Management 131(3): 273-282.

http://dx.doi.org/10.1061/(ASCE)0733-9364(2005)131:3(273)

Jiang, X.; Li, Y. 2009. An empirical investigation of knowledge management and innovative performance: the case of alliances, Research Policy 38(2): 358-368.

http://dx.doi.org/10.1016/j.respol.2008.11.002

Kagioglou, M.; Cooper, R.; Aouad, G. 2001. Performance management in construction: a conceptual framework, Construction Management and Economics 19(1): 85-95.

http://dx.doi.org/10.1080/01446190010003425 
Kaplan, R. S.; Norton, D. P. 1996. The balanced scorecard: translating strategy into action. Boston: Harvard Business School Press.

Ke, Y.; Wang, S. Q.; Chan, A. P. C.; Lam, P. T. I. 2010. Preferred risk allocation in China's public-private partnership (PPP) projects', International Journal of Project Management 28: 482-492. http://dx.doi.org/10.1016/j.ijproman.2009.08.007

Keasey, K.; Watson, G. 1994. The bank financing of small firms in the UK: issues and evidence, Small Business Economics 6: 349-362. http://dx.doi.org/10.1007/BF01065138

Lewis, J. D. 1990. Partnerships for profit-structuring and managing strategic alliance. NY: The Free Press.

Li, H.; Cheng, E. W. L.; Love, P. E. D.; Irani, Z. 2001. Co-operative benchmarking: a tool for partnering excellence in construction, International Journal of Project Management 19: 171-179. http://dx.doi.org/10.1016/S0263-7863(99)00033-2

Liao, Y. C.; Phan, P. H. 2015. Internal capabilities, external structural holes network positions, and knowledge creation, The Journal of Technology Transfer April: 1-20.

http://dx.doi.org/10.1007/s10961-015-9415-x

Ling, F. Y. T.; Ibbs, C. W.; Hoo, W. Y. 2006. Determinants of international architectural, engineering, and construction firms' project success in China, Journal of Construction Engineering and Management 13(2): 206-214. http://dx.doi.org/10.1061/(ASCE)0733-9364(2006)132:2(206)

Lo, T.; Wong, P. S. P.; Cheung, S. O. 2006. Using balanced scorecard (BSC) approach to measure performance of partnering projects, Surveying and Built Environment 17(1): 45- 57.

Lu, M. J. 2015. The decision making impact factors of business operation for construction companies in China: a report commissioned by research action. SHINOHYDRO Company, Fuzhou, China (in Chinese). http://dx.doi.org/10.1016/j.ijproman.2006.08.004

Lu, S.; Yan, H. 2007. An empirical study on incentives of strategic partnering in China: views from construction companies, International Journal of Project Management 25(3): 241-249. http://dx.doi.org/10.1016/j.ijproman.2006.08.004

Lu, W.; Shen, L.; Yam, M. C. H. 2008. Critical success factors for competitiveness of contractors: China study, Journal of Construction Engineering and Management 134(12): 972-982.

http://dx.doi.org/10.1061/(ASCE)0733-9364(2008)134:12(972)

Mahmoodzadeh, S.; Shahrabi, J.; Pariazar, M.; Zaeri, M. S. 2007. Project selection by using fuzzy AHP and TOPSIS technique, World Academic of Science, Engineering and Technology 30: 333-338. http://dx.doi.org/10.1016/j.autcon.2015.07.014

Mohr, J.; Spekman, R. 1994. Characteristics of partnering success: partnering attributes, communication behavior, and conflict resolution techniques, Strategic Management Journal 15(2): 135-152. http://dx.doi.org/10.1002/smj.4250150205

Morris, B. G. A.; Cadogan, J. W. 2001. Partner symmetries, partner conflict and the quality of joint venture marketing strategy: an empirical investigation, Journal of Marketing Management 17: 223-256. http://dx.doi.org/10.1362/0267257012571474

Moselhi, O.; Assem, I.; Ei-Rayes, K. 2005. Chage orders impact on labor productivity, Journal of Construction Engineering and Management March: 354-359.

http://dx.doi.org/10.1061/(ASCE)0733-9364(2005)131:3(354)

NBSC. 2012-2014. China statistical yearbook 2012-2014 [online], [cited 12 June 2015]. National Bureau of Statistics of China. Available from Internet: http://www.stats.gov.cn/tjsj/ndsj/2014/ indexch.htm (in Chinese).

Ozorhon, B.; Arditi, D.; Dikmen, I.; Birgonul, M. 2011. Toward a multidimensional performance measure for international joint ventures in construction, Journal of Construction Engineering and Management 137(6): 403-411. http://dx.doi.org/10.1061/(ASCE)CO.1943-7862.0000314 
Price, A. D. F.; Shawa, H. 1997. Survey of project related finance in United Arab Emirates, Journal of Construction Engineering and Management 123(3): 223-232.

http://dx.doi.org/10.1061/(ASCE)0733-9364(1997)123:3(223)

Saaty, T. L. 1978. Exploring the interface between hierarchies, Multiple Fuzzy Sets and Systems 1: 57- 68. http://dx.doi.org/10.1016/0165-0114(78)90032-5

Samvedi, A.; Jain, V.; Chan, T. S. 2013. Quantifying risks in a supply chain through integration of fuzzy AHP and fuzzy TOPSIS, International Journal of Production Research 5(8): 2433-2442. http://dx.doi.org/10.1080/00207543.2012.741330

Wallack, R. L. 2005. China's project management rules have foreigners fuming [online], [cited 15 October 2014]. Available from Internet: http://enr.construction.com/news/intl/archives/051024. asp

Xiamen Municipal Government. 2009. Encouraging and expanding the investment from private sectors [online], [cited 10 August 2011]. Available from Internet: http://www.big5.xm.gov.cn:82/ zt/kdnxcjjjzz/fjsgykdnx/200906/t20090622_308144.htm (in Chinese).

Xu, T.; Bower, D. A.; Smith, N. J. 2005. Types of collaboration between foreign contractors and their Chinese partners, International Journal of Project Management 23: 45-53.

http://dx.doi.org/10.1016/j.ijproman.2004.05.012

Zou, P. X. W.; Zhang, G.; Wang, J. 2007. Understanding the key risks in construction projects in China, International Journal of Project Management 25: 601-614.

http://dx.doi.org/10.1016/j.ijproman.2007.03.001

Chih-Han KAO (Dr) received the PhD degree from Construction Engineering from National Taiwan University of Science \& Technology in 2007. He is an Assistant Professor of the Department of Civil Engineering and Engineering Management of National Quemoy University, Kinmen, Taiwan. His areas of research include construction management, decision making and data mining embedded Soft Computing.

Cheng-Han HUANG (Dr) is a civil engineer specializing in construction industry and economics. He received PhD degree from University of Chung-Hsing in 2014, he works for Taiwan Construction Research Institute and the government of Taiwan as a director researcher to participate in several projects related to infrastructure system and feasibility and economic analysis.

Mark Shu-Chien Hsu (Dr) was a postdoctoral research associate at the University of Maryland in the Project Management Centre for Excellence prior to joining The Hong Kong Polytechnic University. His primary research goals are using computational modelling techniques, to help understand and analyze complex systems in the fields of project organization and human behaviour, sustainable management, and disaster management.

I-Hung TSAI received the M.S. degree from Civil Engineering and Engineering Management Department from National Quemoy University in 2011. He services in the Cathay Real Estate Development Company as an engineer. 